\title{
PENGARUH MODEL PEMBELAJARAN TANDUR TERHADAP KEMAMPUAN PEMAHAMAN KONSEP DAN PENALARAN MATEMATIS PESERTA DIDIK
}

\author{
Titin Puji Astuti ${ }^{1}$, Rubhan Masykur ${ }^{2}$, Dona Dinda Pratiwi ${ }^{3}$ \\ 1,2,3 Pendidikan Matematika, Universitas Islam Negeri Raden Intan Lampung \\ E-mail: $\frac{\text { astuti.titinpuji19@gmail.com }}{{ }^{\text {rmasykur@yahoo.co.id }}}{ }^{2)}$ \\ donadinda@radenintan.ac.id $^{3)}$
}

Received 8 August 2018; Received in revised form 12 September 2018; Accepted 21 September 2018

\begin{abstract}
The aims of this research to gain the result of effect TANDUR model to mathematical concept understanding and student's mathematical reasoning. This research was quasi experiment with pretestpostest control group design. The population in this research was students of seventh grade SMP N 2 Natar academic year 2017/2018. The sampling technique used random sampling technique and divided onto two groups, experiment group and control group. The results of this research were: 1) there was influence of TANDUR learning model to mathematical concept understanding. 2) there were influence of TANDUR learning model to mathematical reasoning. 3) TANDUR model learning can affect simultaneously of mathematical concept understanding and mathematical reasoning.
\end{abstract}

Keywords: Mathematical concept understanding; Mathematical reasoning; TANDUR learning model.

\section{PENDAHULUAN}

Matematika merupakan salah satu mata pelajaran yang diajarkan pada setiap jenjang pendidikan di Indonesia mulai dari Sekolah Dasar (SD) sampai perguruan tinggi. Matematika merupakan mata pelajaran yang penting, dilihat dari jam mata pelajaran matematika di sekolah lebih banyak dibanding mata pelajaran lainnya. Pentingnya mempelajari matematika dikarenakan ilmu matematika sangat berperan penting dalam kehidupan dan merupakan cabang ilmu yang bermanfaat untuk terjun di masyarakat(Purwanti, Pratiwi, \& Rinaldi, 2016). Selain itu, matematika mempunyai peranan yang penting karena matematika sebagai dasar logika atau penalaran dan penyelesaian kuantitatif yang digunakan dalam pelajaran lainnya(Rahmawati, 2017). Bisa dikatakan, matematika merupakan induk dari semua pengetahuan. Bahkan dalam dunia teknologi maupun kehidupan sehari-hari, banyak yang berhubungan dengan perhitungan angka-angka. Hampir semua hal di dunia ini menggunakan ilmu matematika (Masykur, Nofrizal, \& Syazali, 2017).

Beberapa hal penting dalam matematika adalah kemampuan pemahaman konsep dan penalaran matematis. (Rohmah \& Wahyudin, 2016) menyatakan bahwa dalam pembelajaran matematika pemahaman konsep dan penalaran matematis merupakan kompetensi yang harus dikembangkan pada diri peserta didik. Hal ini dikarenakan pemahaman konsep matematis merupakan landasan penting untuk berpikir dan menyelesaikan permasalahan matematika. Kemampuan pemahaman konsep matematis adalah kemampuan peserta didik dalam menemukan dan menjelaskan, menerjemahkan, menafsirkan, dan menyimpulkan suatu konsep matematika berdasarkan pembentukan pengetahuannya sendiri, bukan sekedar menghafal (Pratiwi, 2016). 
Pentingnya kemampuan pemahaman konsep dalam matematika dikarenakan matematika mempelajari konsep-konsep yang saling berhubungan. Pemahaman dan penguasaan konsep merupakan prasyarat untuk dapat menguasai konsep selanjutnya (Apriandi \& Setyansah, 2017). Ketidakpahaman peserta didik terhadap suatu konsep akan mengakibatkan kesulitan dalam memahami konsep selanjutnya. Peserta didik dengan pemahaman konsep yang baik akan mengetahui lebih dalam mengenai ide-ide matematika yang masih terselubung. Pengetahuan yang dipelajari dengan pemahaman akan memberikan dasar dalam pembentukkan pengetahuan baru, sehingga dapat digunakan dalam memecahkan permasalahan baru (Farida, 2015).

Sedangkan kemampuan penalaran matematis sangat diperlukan guna mengembangkan sikap ilmiah peserta didik. Ruseffendi dalam (Hadi, 2016) mengatakan bahwa matematika terbentuk sebagai hasil pemikiran manusia yang berhubungan dengan ide, proses dan penalaran. Kemampuan menggunakan penalaran sangat penting untuk memahami matematika, dalam mempelajari matematika peserta didik hendaknya mampu mengaitkan pengetahuan yang sudah dimiliki dengan pengetahuan yang sedang dipelajari. Berdasarkan uraian di atas, peningkatan kemampuan pemahaman konsep dan penalaran matematis peserta didik harus terus dikembangkan pada diri peserta didik.

Namun pada kenyataannya kemampuan pemahaman konsep dan penalaran matematis peserta didik masih rendah. Berdasarkan hasil observasi yang dilakukan di kelas VIIA SMP Negeri 2 Natar, terlihat bahwa kegiatan pembelajaran di kelas masih berpusat pada guru. Dalam pembelajaran, guru lebih menekankan pada proses penyampaian materi secara lisan, sedangkan peserta didik kurang terlibat aktif dalam pembelajaran. Proses pembelajaran yang terjadi di dalam kelas adalah peserta didik diberikan definisi suatu materi/konsepkonsep, dicatatkan rumus di papan tulis, dan peserta didik menyalinnya di buku catatan, terlihat bahwa peserta didik tidak dilibatkan dalam menemukan sebuah konsep. Berdasarkan karakteristik yang ada, maka dapat dikatakan bahwa model pembelajaran yang digunakan guru pada kegiatan belajar di kelas adalah model pembelajaran konvensional dengan tipe ekspositori.

Model pembelajaran ekspositori adalah model pembelajaran yang masih berpusat pada guru. Pembelajaran seperti ini memposisikan peserta didik sebagai objek yang pasif dan tidak memberi pengalaman langsung kepada peserta didik untuk membangun pemahaman sendiri terhadap materi yang sedang dipelajari. Akibatnya, pada saat guru meminta peserta didik untuk menyatakan ulang konsep, sebagian besar peserta didik mengalami kesulitan dalam menyebutkan kembali konsep yang telah mereka pelajari. Hal ini menunjukkan pemahaman konsep peserta didik masih rendah. Selain itu, apabila guru memberikan soal yang sedikit berbeda dengan contoh, peserta didik mengalami kesulitan dalam menjawabnya, terlihat bahwa penalaran matematis peserta didik juga masih rendah.

Hal ini sejalan dengan penelitian Eka P, I. W., Sadia, I. W., \& Suastra, I. W. bahwa pembelajaran di sekolah masih cenderung berbasis hafalan teori bukan berdasarkan pada pengalaman peserta didik. Guru lebih banyak berperan aktif mentransfer pengetahuan, sehingga membatasi ruang gerak peserta didik dalam mengembangkan potensinya 
untuk memperdalam pemahaman konsep (Eka P, Sadia, \& Suastra, 2014). Selain itu, Riyanto dalam (Rohmah \& Wahyudin, 2016) menyatakan bahwa penyebab kurangnya kemampuan penalaran matematis peserta didik dikarenakan dalam proses pembelajaran matematika di kelas kurang melibatkan peserta didik.

Untuk menunjang kemampuan pemahaman konsep dan penalaran matematis peserta didik, diperlukan pembelajaran yang dapat membuat peserta didik aktif dan menjadikan pembelajaran lebih bermakna. Salah satu model pembelajaran yang dapat membuat proses belajar menjadi lebih aktif, bermakna, dan menyenangkan bagi peserta didik adalah model pembelajaran TANDUR. TANDUR merupakan akronim dari kata Tumbuhkan, Alami, Namai, Demonstrasi, Ulangi, dan Rayakan yang merupakan kerangka pembelajaran Quantum Teaching.

Model pembelajaran TANDUR merupakan model pembelajaran yang membuat kegiatan pembelajaran menjadi lebih bermakna bagi peserta didik karena peserta didik mengalami apa yang sedang dipelajari bukan sekedar melihat atau menghafal (Kurniyati, 2016). Menurut Wankat dan Oreovocz teknik pemberian pengalaman langsung kepada peserta didik dalam proses pembelajaran akan meningkatkan dan mempermudah pemahaman peserta didik terhadap isi pembelajaran (Wena, 2009). Selain itu, pembelajaran TANDUR merupakan salah satu model pembelajaran untuk meningkatkan aktivitas peserta didik (Fermantika, 2012). Menurut Anderson, pembelajaran dengan strategi aktif seperti diskusi, percobaan, dan belajar kelompok dapat meningkatkan penalaran matematis yang merupakan salah satu faktor sukses dalam pembelajaran matematika (Yosefa \& Nurjanah, 2006).

Tujuan penelitian ini adalah untuk mengetahui (1) Apakah terdapat pengaruh model pembelajaran TANDUR terhadap kemampuan pemahaman konsep matematis peserta didik, (2) Apakah terdapat pengaruh model pembelajaran TANDUR terhadap kemampuan penalaran matematis peserta didik, dan (3) Apakah model pembelajaran TANDUR dapat berpengaruh terhadap pemahaman konsep dan penalaran matematis peserta didik secara simultan.

\section{METODE PENELITIAN}

Penelitian ini menggunakan metode quasi eksperimen dengan desain penelitian pretest-postest control group design. Dalam penelitian ini yang menjadi variabel bebas (X) adalah "Model pembelajaran TANDUR", sedangkan yang menjadi variabel terikat (Y) adalah "kemampuan pemahaman konsep (Y1)" dan "kemampuan penalaran matematis (Y2)". Adapun indikator pemahaman konsep yang akan digunakan dalam penelitian ini yaitu menurut Peraturan Dirjen Dikdasmen Depdiknas Nomor 506/C/Kep/PP/2004, yaitu:
a. Menyatakan ulang sebuah konsep.
b. Mengklasifikasikan objek menurut sifat-sifat tertentu sesuai dengan konsepnya.
c. Memberi contoh dan bukan contoh dari suatu konsep.
d. Menyajikan konsep dalam berbagai bentuk representasi matematis.
e. Mengembangkan syarat perlu atau syarat cukup dari suatu konsep.
f. Menggunakan dan memanfaatkan tertentu. serta memilih prosedur atau operasi
g. Mengaplikasikan konsep atau algoritma pada pemecahan masalah.


Sedangkan indikator penalaran matematis yang harus dicapai peserta didik berdasarkan peraturan Dirjen Dikdasmen No.506/C/PP/2004 diantaranya, yaitu:

a. Kemampuan mengajukan dugaan.

b. Kemampuan melakukan manipulasi matematika.

c. Kemampuan menarik kesimpulan, menyusun bukti, memberikan alasan atau bukti terhadap kebenaran solusi.

d. Kemampuan menarik kesimpulan dari pernyataan.

e. Kemampuan memeriksa kesahihan suatu argumen.

f. Kemampuan menemukan pola atau sifat dari gejala matematis untuk membuat generalisasi.

Penelitian ini dikelompokkan menjadi dua kelompok yaitu kelompok pertama adalah kelompok eksperimen dengan menggunakan model pembelajaran TANDUR dan kelompok kedua adalah kelompok kontrol dengan menggunakan pembelajaran ekspositori.

Instrumen penelitian yang digunakan dalam pengumpulan data adalah tes essay (tes kemampuan pemahaman konsep dan penalaran matematis). Populasi dalam penelitian ini adalah seluruh kelas VII SMP Negeri 2 Natar Tahun Ajaran 2017/2018 dengan jumlah 186 peserta didik. Pengambilan sampel dengan teknik acak kelas memperoleh sampel kelas eksperimen dengan jumlah 32 peserta didik dan kelas kontrol dengan jumlah 31 peserta didik. Analisis data dalam penelitian ini menggunakan uji N-Gain dan uji Manova. Uji N-Gain digunakan untuk mengetahui besarnya peningkatan kemampuan pemahaman konsep dan penalaran metematis peserta didik antara nilai pretest dengan nilai posttest, sedangkan uji manova digunakan untuk mengetahui pengaruh model pembelajaran TANDUR terhadap pemahaman konsep dan penalaran matematis secara simultan.

Prosedur dalam penelitian ini adalah: (1) Menyiapkan Rencana Pelaksanaan Pembelajaran (RPP) dengan menerapkan model pembelajaran TANDUR, (2) Menyiapkan instrumen penelitian berupa tes pemahaman konsep dan penalaran matematis (tes essay), (3) Melaksanakan uji coba instrumen untuk menentukan validitas dan reliabilitasnya, (4) Memberikan tes awal (pretest) kemampuan pemahaman konsep dan penalaran matematis, (5) Melaksanakan pembelajaran yaitu dengan memberikan perlakuan pada kelas eksperimen dan kelas kontrol, (6) Memberikan tes akhir (posttest) kemampuan pemahaman konsep dan penalaran matematis, (7) Pengolahan data.

Adapun hipotesis pada penelitian ini adalah sebagai berikut:

$\mathrm{H}_{0 \mathrm{~A}} \quad=$ Tidak terdapat pengaruh model pembelajaran TANDUR terhadap kemampuan pemahaman konsep matematis peserta didik.

$\mathrm{H}_{1 \mathrm{~A}}=$ Terdapat pengaruh model pembelajaran TANDUR terhadap kemampuan pemahaman konsep matematis peserta didik.

$\mathrm{H}_{0 \mathrm{~B}}=$ Tidak terdapat pengaruh model pembelajaran TANDUR terhadap kemampuan penalaran matematis peserta didik.

$\mathrm{H}_{1 \mathrm{~B}}=$ Terdapat pengaruh model pembelajaran TANDUR terhadap kemampuan penalaran matematis peserta didik.

$\mathrm{H}_{0 \mathrm{C}}=$ Model pembelajaran TANDUR tidak dapat berpengaruh terhadap pemahaman konsep dan 


\section{penalaran matematis peserta didik secara simultan. \\ $\mathrm{H}_{1 \mathrm{C}}=$ Model pembelajaran TANDUR dapat berpengaruh terhadap pemahaman konsep dan penalaran matematis peserta didik secara simultan.}

Dengan kriteria keputusan:

Jika nilai signifikansi > 0.05, maka Ho diterima

Jika nilai signifikansi $<0.05$, maka Ho ditolak

\section{HASIL PENELITIAN DAN PEMBAHASAN}

Berdasarkan perhitungan uji prasyarat yang dilakukan, data telah memenuhi syarat yaitu berasal dari populasi yang berdistribusi normal dan bervariansi homogen. Untuk mengetahui besarnya peningkatan kemampuan pemahaman konsep dan penalaran metematis peserta didik, digunakan rumus $\mathrm{N}$-Gain yaitu skor posttest dikurangi skor pretest kemudian dibagi dengan skor maksimum dikurangi skor pretest. Adapun hasil dari perhitungan N-Gain pada Tabel 1.

Tabel 1. Nilai N-Gain

\begin{tabular}{|c|c|c|c|}
\hline \multirow[b]{2}{*}{ Kelas } & \multirow[b]{2}{*}{ Nilai } & \multicolumn{2}{|c|}{ Variabel } \\
\hline & & $\begin{array}{c}\text { N-Gain } \\
\text { Pemahaman } \\
\text { Konsep }\end{array}$ & $\begin{array}{c}\text { N-Gain } \\
\text { Penalaran } \\
\text { Matematis }\end{array}$ \\
\hline \multirow{3}{*}{ Eksperimen } & Minimal & 0.091 & 0.083 \\
\hline & Maksimal & 0.857 & 0.818 \\
\hline & Rata-rata & 0.450 & 0.456 \\
\hline \multirow{3}{*}{ Kontrol } & Minimal & 0.000 & 0.091 \\
\hline & Maksimal & 0.769 & 0.600 \\
\hline & Rata-rata & 0.292 & 0.128 \\
\hline
\end{tabular}

Berdasarkan Tabel 1. terlihat nilai rata-rata N-Gain kemampuan pemahaman konsep pada kelas eksperimen adalah 0.450 yang berarti bahwa nilai rata-rata peningkatan kemampuan pemahaman konsep peserta didik pada kelas eksperimen sebesar 0.450 dan nilai rata-rata $\mathrm{N}$-Gain kemampuan pemahaman konsep matematis pada kelas kontrol adalah 0.292 . Sedangkan nilai rata-rata $\mathrm{N}-$ Gain kemampuan penalaran matematis pada kelas eksperimen adalah 0.456 yang berarti bahwa nilai rata-rata peningkatan kemampuan pemahaman konsep peserta didik pada kelas eksperimen sebesar 0.450 dan nilai rata-rata $\mathrm{N}$-Gain kemampuan penalaran matematis pada kelas kontrol adalah 0.128. Dengan nilai $\mathrm{N}$-Gain tersebut dapat diketahui bahwa peningkatan kemampuan pemahaman konsep dan penalaran metematis peserta didik kelas eksperimen lebih baik jika dibandingkan dengan kelas kontrol.

Untuk menguji perbedaan kemampuan pemahaman konsep dan penalaran matematis peserta didik pada kelas eksperimen dan kelas kontrol menggunakan uji manova. Adapun hasil dari uji manova pada Tabel 2. 
ISSN 2089-8703 (Print) Vol. 7, No. 2 (2018) 201-209

ISSN 2442-5419 (Online)

Tabel 2. Uji Manova terhadap kemampuan pemahaman konsep dan penalaran matematis secara individu

Tests of Between-Subjects Effects

\begin{tabular}{|lr|r|r|r|r|r|}
\hline \multirow{2}{*}{ Source } & $\begin{array}{c}\text { Dependen } \\
\mathrm{t} \text { Variable }\end{array}$ & $\begin{array}{c}\text { Type III Sum } \\
\text { of Squares }\end{array}$ & $\mathrm{df}$ & Mean Square & \multicolumn{1}{c|}{$\mathrm{F}$} & \multicolumn{1}{c|}{ Sig. } \\
\hline Corrected & $\mathrm{n}$ gain PK & $.395^{\mathrm{a}}$ & 1 & .395 & 9.813 & .003 \\
Model & $\mathrm{n}$ gain PM & $.561^{\mathrm{b}}$ & 1 & .561 & 24.357 & .000 \\
\hline Intercept & $\mathrm{n}$ gain PK & 8.679 & 1 & 8.679 & 215.470 & .000 \\
& $\mathrm{n}$ gain PM & 8.241 & 1 & 8.241 & 358.098 & .000 \\
\hline Model & $\mathrm{n}$ gain PK & .395 & 1 & .395 & 9.813 & .003 \\
& $\mathrm{n}$ gain PM & .561 & 1 & .561 & 24.357 & .000 \\
\hline Error & $\mathrm{n}$ gain PK & 2.457 & 61 & .040 & & \\
& $\mathrm{n}$ gain PM & 1.404 & 61 & .023 & & \\
\hline Total & $\mathrm{n}$ gain PK & 11.593 & 63 & & & \\
& $\mathrm{n}$ gain PM & 10.276 & 63 & & & \\
\hline Corrected Total $\mathrm{n}$ gain PK & 2.852 & 62 & & & \\
& $\mathrm{n}$ gain PM & 1.964 & 62 & & & \\
\hline
\end{tabular}

a. R Squared $=.139$ (Adjusted R Squared $=.124)$

b. $\mathrm{R}$ Squared $=.285($ Adjusted R Squared $=.274)$

Berdasarkan Tabel 2 dapat dilihat pada baris model, pada angka signifikansi N-Gain Pemahaman Konsep (PK) diperoleh nilai signifikansi sebesar 0.003. Karena nilai signifikansi kurang dari nilai alpha yang ditetapkan yaitu 0.05 , artinya $\mathrm{H}_{0 \mathrm{~A}}$ ditolak, sehingga dapat disimpulkan bahwa terdapat pengaruh model pembelajaran TANDUR terhadap kemampuan pemahaman konsep matematis peserta didik.

Berdasarkan Tabel 2 juga dapat dilihat pada baris model, pada angka signifikansi N-Gain Penalaranan Matematis (PM) diperoleh nilai signifikansi sebesar 0.000. Karena nilai signifikansi kurang dari nilai alpha yang ditetapkan yaitu 0.05 , artinya $\mathrm{H}_{0 \mathrm{~B}}$ ditolak sehingga dapat disimpulkan bahwa terdapat pengaruh model pembelajaran TANDUR terhadap kemampuan penalaran matematis peserta didik.

Sedangkan untuk menguji perbedaan kemampuan pemahaman konsep dan penalaran matematis peserta didik antara kelas eksperimen dan kelas kontrol secara simultan menggunakan uji manova. Adapun hasil dari uji manova pada Tabel 3. 
Tabel 3. Uji Manova terhadap kemampuan pemahaman konsep dan penalaran matematis secara simultan

Multivariate Tests ${ }^{\mathrm{b}}$

\begin{tabular}{|ll|r|r|r|r|r|}
\hline Effect & \multicolumn{1}{|c|}{ Value } & \multicolumn{1}{c|}{ F } & Hypothesis df & Error df & \multicolumn{1}{c|}{ Sig. } \\
\hline Intercept & Pillai's Trace & .879 & $217.640^{\mathrm{a}}$ & 2.000 & 60.000 & .000 \\
& Wilks' Lambda & .121 & $217.640^{\mathrm{a}}$ & 2.000 & 60.000 & .000 \\
& Hotelling's Trace & 7.255 & $217.640^{\mathrm{a}}$ & 2.000 & 60.000 & .000 \\
& 7.255 & $217.640^{\mathrm{a}}$ & 2.000 & 60.000 & .000 \\
& Roy's Largest & & & & \\
\hline Root & .308 & $13.340^{\mathrm{a}}$ & 2.000 & 60.000 & .000 \\
\hline Model & Pillai's Trace & .692 & $13.340^{\mathrm{a}}$ & 2.000 & 60.000 & .000 \\
& Wilks' Lambda & .445 & $13.340^{\mathrm{a}}$ & 2.000 & 60.000 & .000 \\
& Hotelling's Trace & .445 & $13.340^{\mathrm{a}}$ & 2.000 & 60.000 & .000 \\
& & & & & \\
\hline
\end{tabular}

a. Exact statistic

b. Design: Intercept + Model

Berdasarkan Tabel 3 dapat dilihat pada baris model, dimana nilai signifikansi yang diuji dengan prosedur Pillai's Trace, Wilks' Lambda, Hotelling's Trace, dan Roy's Largest Root adalah 0.000. Karena nilai signifikansi kurang dari nilai alpha yang ditetapkan yaitu 0.05 , artinya $\mathrm{H}_{0 \mathrm{C}}$ ditolak, sehingga dapat disimpulkan bahwa model pembelajaran TANDUR dapat berpengaruh terhadap kemampuan pemahaman konsep dan penalaran matematis peserta didik secara simultan.

Berkaitan dengan hasil analisis $\mathrm{N}$ Gain, dimana rata-rata N-Gain kelas eksperimen lebih tinggi dibanding dengan kelas kontrol, terlihat bahwa pembelajaran dengan menggunakan model TANDUR memiliki pengaruh yang lebih baik terhadap kemampuan pemahaman konsep dan penalaran matematis peserta didik. Model pembelajaran TANDUR berpengaruh terhadap peningkatan kemampuan pemahaman konsep matematis dikarenakan model pembelajaran
TANDUR merupakan model pembelajaran yang menjadikan pembelajaran lebih bermakna bagi peserta didik karena peserta didik mengalami apa yang sedang dipelajari bukan sekedar melihat atau menghafal. Dengan pemberian pengalaman langsung kepada peserta didik, peserta didik lebih mudah dalam memahami konsep materi yang dipelajari, sehingga kemampuan pemahaman konsepnya menjadi lebih baik.

Selain itu, melalui model pembelajaran TANDUR pembelajaran menjadi berpusat pada peserta didik dan membiarkan peserta didik lebih banyak aktif dalam proses pembelajaran. Sikap aktif peserta didik dalam menghadapi persoalan matematika yang sedang dipelajari membuat kemampuan penalaran matematisnya lebih berkembang. Sedangkan di dalam pembelajaran ekspositori, materi pembelajaran di sampaikan langsung oleh guru kepada peserta didik. Peserta didik hanya mendengar, menyimak dan mencatat apa yang disampaikan guru. 
Peserta didik tidak menemukan sendiri konsep materi yang dipelajari. Sehingga, peserta didik masih kesulitan dalam menyatakan ulang konsep. Selain itu, proses pembelajaran tidak membuat peserta didik aktif dalam pembelajaran. Hal ini membuat peserta didik mengalami kesulitan dalam menyelesaikan soal yang berbeda dengan contoh yang diberikan guru.

Dengan demikian, pembelajaran TANDUR cocok diterapkan dalam proses pembelajaran. Hal ini dikarenakan dalam proses pembelajaran, model pembelajaran TANDUR dapat membuat peserta didik lebih aktif dalam pembelajaran dan membuat peserta didik mampu menemukan sendiri konsep yang dipelajari sehingga kemampuan pemahaman konsep dan penalaran matematisnya dapat meningkat.

\section{KESIMPULAN DAN SARAN}

\section{Kesimpulan}

Berdasarkan hasil analisis data dan pembahasan, dapat disimpulkan bahwa:
1. Terdapat pengaruh model pembelajaran TANDUR terhadap kemampuan pemahaman konsep matematis peserta didik.

2. Terdapat pengaruh model pembelajaran TANDUR terhadap kemampuan penalaran matematis peserta didik.

3. Model pembelajaran TANDUR dapat berpengaruh terhadap kemampuan pemahaman konsep dan penalaran matematis peserta didik secara simultan.

4. Melalui model pembelajaran TANDUR yang menjadikan pembelajaran lebih bermakna, dimana peserta didik mengalami langsung apa yang dipelajarinya bukan sekedar melihat atau menghafal membuat peserta didik lebih mudah memahami konsep materi yang dipelajari sehingga pemahaman konsep peserta didik yang mendapat pembelajaran TANDUR lebih baik dibanding dengan peserta didik yang mendapat pembelajaran eksositori.

5. Melalui pembelajaran TANDUR pembelajaran menjadi berpusat pada peserta didik dan membuat peserta didik lebih banyak aktif dalam pembelajaran. Sikap aktif peserta didik menghadapi persoalan matematika yang dipelajarinya membuat kemampuan penalaran matematisnya lebih berkembang.

\section{Saran}

Berdasarkan kesimpulan dari hasil penelitian, ada beberapa saran, yaitu:

1. Dalam mengajarkan matematika kepada peserta didik, pendidik dapat menggunakan model pembelajaran yang memberikan pengalaman langsung kepada peserta didik untuk mencari dan menemukan sendiri konsep materi yang dipelajari serta menjadikan peserta didik aktif terlibat dalam proses pembelajaran. Salah satunya yaitu model pembelajaran TANDUR. Hal ini diharapkan agar peserta didik lebih mudah memahami materi dan kemampuan bernalarnya lebih meningkat.

2. Kepada peneliti lain yang akan menerapkan model pembelajaran TANDUR dapat menerapkan pada pokok bahasan lain dan mengetahui pengaruh model pembelajaran TANDUR pada aspek-aspek kemampuan matematis yang lain. 


\section{DAFTAR PUSTAKA}

Apriandi, D., \& Setyansah, R. K. (2017). Penerapan Media Simulasi Matlab Berbasis Interactive Conceptual Untuk meningkatkan pemahaman Konsep Mahasiswa. Aksioma: Jurnal Pendidikan Matematika FKIP Univ. Muhammadiyah Metro., 6(2), 159167.

Eka P, I. W., Sadia, I. W., \& Suastra, I. W. (2014). Pengaruh Model Pembelajaran Perubahan Konseptual Terhadap Pemahaman Konsep Peserta didik Ditinjau Dari Gaya Kognitif. E-Journal Program Pascasarjana Universitas Pendidikan Ganesha Program Studi, 4(2).

Farida. (2015). Pengaruh Strategi Pembelajaran Heuristic Vee Terhadap Kemampuan Pemahaman Konsep Matematis Peserta Didik. Al-Jabar: Jurnal Pendidikan Matematika, 6(2), 111-119.

Fermantika, E. (2012). Penerapan Metode TANDUR Pada Pembelajaran Matematika Siswa Kelas VIII SMPN 12 Padang. Jurnal Pendidikan Matematika, 1(1), 50-54.

Hadi, W. (2016). Meningkatkan Kemampuan Penalaran Siswa SMP Melalui Pembelajaran Discovery Dengan Pendekatan Saintifik. Jurnal Pendidikan Matematika, I(1), 93-108.

Kurniyati, D. (2016). Peningkatan Hasil Belajar IPS Dengan Menerapkan Model Pembelajaran Quantum Teaching Di SD N Balong. Jurnal Pendidikan Guru Sekolah Dasar.

Masykur, R., Nofrizal, \& Syazali, M. (2017). Pengembangan Media Pembelajaran Matematika dengan Macromedia Flash. Al-Jabar:
Jurnal Pendidikan Matematika, 8(2), 177-185.

Pratiwi, D. D. (2016). Pengaruh Pembelajaran Berbantuan Geogebra terhadap Pemahaman Konsep Matematis ditinjau dari Gaya Kognitif. Al-Jabar: Jurnal Pendidikan Matematika, 7(2), 191-201.

Purwanti, R. D., Pratiwi, D. D., \& Rinaldi, A. (2016). Pengaruh Pembelajaran Berbantuan Geogebra Terhadap Pemahaman Konsep Matematis Ditinjau Dari Gaya Kognitif. Al-Jabar: Jurnal Pendidikan Matematika, 7(1), 115-122.

Rahmawati, N. K. (2017). Implementasi Teams Games Tournamens dan Number Head Together ditinjau dari Kemampuan Penalaran Matematis. Jurnal Pendidikan Matematika, 8(2), 121-134.

Rohmah, E. A., \& Wahyudin. (2016). Pengaruh Pembelajaran Kooperatif Tipe TGT Berbantuan Media Game Online Terhadap Pemahaman Konsep dan Penalaran Matematis Siswa. Jurnal Pendidikan Dasar, 8(2), 126-143.

Wena, M. (2009). Strategi Pembelajaran Inovatif Kontemporer: Suatu Tinjauan Konseptual Operasional. Jakarta: Bumi Aksara.

Yosefa, B., \& Nurjanah, E. (2006). Pengaruh Metode Pembelajaran Quantum Teaching Dengan Menggunakan Mind Mapping Terhadap Kemampuan Penalaran Matematis Pada Siswa SMP Kelas VIII. Jurnal Pengajaran MIPA, 18(2), 146-151. 